\title{
THE FUTURE OF THE LOAN SHARK AND CONSUMER CREDIT AGENCIES
}

\author{
LeON Henderson*
}

The July, 1953, issue of the Federal Reserve Bulletin noted, with no explicit reference to its goodness or badness, that consumer installment credit had increased nearly five billion dollars, or $3^{\mathrm{I}}$ per cent, in the preceding year. The Bulletin also recorded that the ratio of consumer installment credit had climbed in the past year from 6.6 to 8.I per cent of consumer disposable income, and reached the highest level in the country's financial history.

The Comptroller of the Currency, in his annual report on national banks, released in August of I953, said that some national banks have liberalized personal loan policies "beyond the point of prudence."

Loan sharkery was not mentioned by either authority, and it is not suggested that they have any primary responsibility to protect necessitous borrowers.

It is yet true that many of the transactions included in the Federal Reserve Board's statistics would not survive a factual test for usury, nor do the statistics include the figures of the out-and-out loan shark business as it persists in many states today.

Nevertheless the clear and present danger exists, and the problems should be delineated.

Mass financing is a concomitant of mass production and mass distribution, and protection to borrowers has not kept pace with the ever-rising use of consumer credit.

\section{I}

\section{Legislation Affecting Consumer Credit-Effectiveness and Failings}

\section{A. The Uniform Small Loan Law}

Very early in this century the Russell Sage Foundation recognized the abuses suffered from loan sharks by wage and salary earners. It saw quickly that the general usury laws afforded no protection to such borrowers. In fact, the usury laws served to deny access to small borrows of credit on decent terms. The Foundation therefore drafted and urged state legislatures to adopt its Uniform Small Loan Law. This law spelled out necessary protections, under state supervision and penalties, which drove the old-time wage, chattel and salary-buying loan shark, with his 20 per cent a month charges, out of business in the well-regulated states.

The law provided for a system of licensed lending, at fair rates, to meet the emergent needs of consumers without other means of financing. Given strict in-

*A.B. I920, Swarthmore College. Director, Consumer Credit Research, Russell Sage Foundation, I925-1934; consulting economist, Research Institute of America. 
terpretation, none of the lesser-rate and more business-like loan schemes and devices for evasion through rate concealment, fees, phony certificate purchases, etc. could survive. The law intended exemption only to lending forms for which legislation had been adopted, such as banks, building and loan societies, licensed pawn brokers, etc.

At present there are 36 states which have either adequate small loan laws or permit valid, licensed small loan operations. These states contain approximately 80 per cent of the population. In any of the states lacking a full set of Uniform Law provisions, and in the 12 unregulated states, the loan shark is present. Frequently the high-rate loan office is a unit of loan shark chains which legal aid societies, better business bureaus, junior chambers of commerce, and other public-spirited bodies have been trying to eliminate for a quarter century or more. Their success has encouraged a group of bold newcomers who find demand for small loans from the increasing number of wage earners drawn into the unregulated areas by the rapid pace of decentralization and particularly by growing Southern industrialization. ${ }^{1}$

In the 36 regulated states, the supervised lender is available, and the outstanding loan balance of licensees is roughly 1.5 billion dollars. There has been a trend in these states in recent years toward reduction in rates and increase in the authorized maximum loan to keep pace with the rising price level. The calibre of state supervisors, while still short of full requirement, has been on the up-grade, and this change reflects itself in fewer abuses, better accounting and reporting methods, and the raising of standards generally.

\section{B. Legal Basis of Other Specialized Consumer Credit Agencies}

The potentials of mass production began to be realized during World War I, when long before the United States was drawn into the conflict, its industrial system was busy with war orders from those countries which were to be our allies later. Already the wide demands for automobiles had made possible and profitable the use of new techniques of production, which were available for munitions manufacturing. Coincident with, and energized by these new demands for automobiles and war goods, came the rise of modern industrial engineering methods, of which the most famous at the time was the Taylor System.

The trend of movement of workers to the cities was therefore accelerated, and later the war-developed techniques were so usable in the automobile and other consumer durable goods industries that the wage earner trek was continued. The mass production of automobiles required an efficient scheme of financing purchases by the wage earner class, which became the best market for the new transportation. The cost of the auto was so large relative to worker's cash resources that the market for cars could not have been so great without installment financing.

Does this capsule recounting seem far-removed from the problem of the loan shark?

Hardly. The stimulation of the movement of wage earners to the cities together

\footnotetext{
1 These twelve states, plus the District of Columbia, are Alabama, Arkansas, Delaware, Georgia, Kansas, Mississippi, Montana, North Carolina, North Dakota, South Carolina, Tennessee, and Texas.
} 
with the expansion of the automobile market through installment sales also made a new market for small loans and extensions of credit of many types. The down payments and substantial monthly installments in cash often required the buyer to seek other consumer financing. The small loan business felt the impact, of course. So did the 20 per cent loan shark, especially the salary buyer.

But other types of credit-extending agencies, aware of the expanding needs of consumers and aware, too, of the relatively small loss from bad debts ratio, also geared up to extend credit.

These agencies are identified and discussed elsewhere in this symposium.

For the purposes of this paper, it is sufficient to note that during the twenties, many banks entered into the small loan field, industrial loan companies and the so-called industrial banks, best exemplified by the Morris Plan, extended their operations, and sales finance companies began to make consumer loans as well as financing paper growing out of sales of automobiles and other consumer goods. There were many other proliferations.

Central to the plans for charging for the use of money or credit was the clear recognition that the simple interest rate permitted by usury laws was insufficient, except for banks loaning deposit funds in some states. Also, the Uniform Law provisions added to the dangers of loaning at rates above the customary rate to business by threats to loss of capital and freedom of movement.

Procedures of these specialized agencies varied from state to state. In some jurisdictions they sought and obtained exemption from the small loan law. In others, they sought and obtained special enabling acts to gain legitimacy. Usually these acts had a minimum of legal verbiage to validate the lending scheme, and a minimum of protection for borrowers under the scheme. In no case-not even in states where the Uniform Law was not in force-did these enabling acts recognize with extra legal safeguards the necessity for protecting all uses of consumer credit. Only the Uniform Small Loan Law did this.

Let it be said that most of the lending by the new agencies, such as the personal loan departments of banks, helped to fill a real need at fair rates, thus immensely reducing the high-rate potential.

But since the largest portion of consumer credit was financed under these new procedures, and mainly by banking institutions, subsidiaries of established manufacturing businesses, and reputable commercial credit houses, a certain kind of validity was given at first to their practices for evasion by lack of clear statement of rates charged to users. When a minority took advantage of this validation to exact excessive charges, the sheer volume represented substantial loan sharkery.

As the Guaranty Survey of January, $1953^{2}$ pointed out in an able article, there was no excessive liquidation of consumer credit in the depression years from r9291934. The ratio between personal income and consumer debt remained almost exactly the same.

${ }^{2}$ Hosv Large Is Consumer Credit?, The Guaranty Survey, January, 1953, p. I (published by the Guaranty Trust Company of New York). 
But the internal strains and stresses of the period evoked reexamination of consumer credit practices and legislation. The pressure for lower extra-legal rates developed, and the movement to require new uniform small loan licenses to meet requirements of convenient and advantage gained ground. In the field outside the Uniform Law, public opinion-to use a term subsuming all well-intentioned interests-moved to add to regulatory laws for personal loan departments of banks, discount companies, and industrial lenders. World War II caused a temporary let-up, but the legislative activities in this field were aggressively begun again in the late forties. The new legislation has emphasized the requirement of refunds for prepayments by borrowers to banks, industrial loan companies, and sales finance companies, as well as the need for importing into enabling acts some of the borrower protections of the Uniform Law, such as honest advertising, etc.

The history of usury laws and consumer credit is studded with ingenious schemes to avoid or evade statutory interest maxima. The recent swell of legislative activity has drawn public and court attention to abuses arising from sales of credit insurance to users of consumer credit. Independent of any discussion of the economic need of a borrower for credit insurance, it is clear that some plans are plain loan shark rackets. When sold by a lender, there is duress present, and when the lender obtains a concealed profit from commissions, on an earned basis, from 40 per cent to as much as 80 per cent of the premium collected, no tortured reasoning can divert attention from its evident extortionate charge for the use of credit. ${ }^{3}$

\section{Summary}

The Uniform Small Loan Law has been effective in providing a system of lending for small buyers in most states with large industrial populations. It has been effective in ridding many states of the 20 per cent per month loan shark. The law has fallen far short as a regulatory act for the newer forms of credit extension gaining momentum after World War I. Recently, the law's standards for borrower safeguarding are being used as a guide for regulation of all consumer lending.

\section{II}

\section{Some Economic Factors Affecting the Future of Consumer Credit}

\section{A. Demand for Consumer Credit}

Back in the late twenties, when there were less than half a dozen economists observing consumer credit on a full time basis, your author was considered an expert. In the absence of official statistics, it was possible to guesstimate that the volume of installment financing of sales to consumers outstanding in 1929 was roughly 2.5 billion dollars, and that the volume of outstanding cash loans by legitimate agencies was about 700 million dollars.

Recently this year the Federal Reserve Board revised its consumer credit statistics

\footnotetext{
${ }^{3}$ For a recent discussion, see Parish, Credit Life, Health and Accident Insurance and the Small Loan Industry, 6 N. M. Bus. 3 (College of Bus. Admin., U. of New MeXrco, June, I953).
} 
and the estimate of outstanding installment credit was increased 2.I billion dollars in the process!

The figures for June, $x 953^{4}$ show a total of installment credit of $\$ 20,489,000,000$, made up as follows:

Consumer Credit, by Major Parts (Estimated Amounts Outstanding, in Millions of Dollars)

\section{Installment Credit}

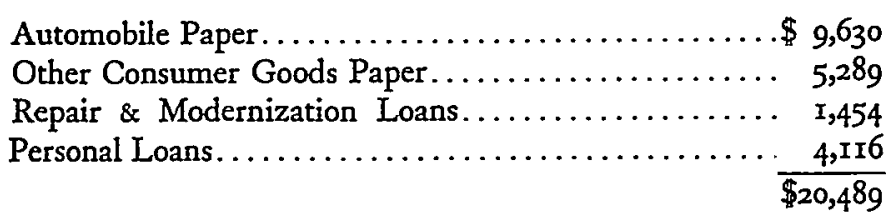

(The total for all consumer credit was 27 billion dollars in June, r953)

For significance, the recent 20.4 billion dollars total needs to be compared with a similar figure of 5.5 billion dollars for 1940, 8.9 billion dollars in 1948, and 14.8 billion dollars in I95x.

Certainly the consumer has been taking increased advantage of his opportunities for credit. One quarter of the total outstanding, or about 5.I billion dollars, has been added since May, 1952 , when Regulation W, the consumer credit regulation, was suspended.

Department of Commerce credit experts, reported Business Week recently, ${ }^{5}$ were not worried by the high figures, and pointed out that the total is probably about ro per cent of income after taxes, while in 1940 the ratio was ro.8 per cent.

But federal officials responsible for banking, credit and monetary policy have been alarmed at the pace and volume of this expansion. The new hard money policy has been applied through banking institutions to dampen grants of credit to consumer credit agencies. But many of the larger finance companies have access to the capital market for sale of their own securities and obtain loan funds independent of banks at times.

It seems probable at this writing that if the rise continues, the Congress will be asked to reimpose Regulation W.

A move to restore federal regulation of the volume of consumer credit would rekindle a bitter controversy as to the impact of such credit on the business cycle and inflation. The would-be controllers will probably argue again that expansion of the consumer sector of credit adds to the spiral of inflation and prevents a decline in consumer prices, which have inched up despite declines in farm and other wholesale prices. Argument will be heard that a dampening of consumer credit will provide a backlog of deferred consumer demand to help fill in the gap caused by an expected decline in business activity.

\footnotetext{
'Statistics on Short and Intermediate-Term Consumer Credit, 39 FED. REs. BuLL. 882 (August, 1953).

${ }^{B}$ More Borrowing, Business Week, May 2, I953, p. 32.
} 
The tantalizing temptation to state the rebuttal arguments will be resisted here, though the reader can be assured that an ex-bureaucrat who participated in framing and administering the war-time Regulation $W$ has heard most of them. Most of the pro-control theses, though logical in theory, have yet to be proved, mainly because the consumer refuses to be logical. Writing about the instability of consumer spending, Arthur F. Burns had the following to say: ${ }^{B}$

Few, if any, economists are any longer disposed to question the capacity of consumers to change their rates of spending and saving without prior notice. Indeed, there is some danger that the whimsical character of consumer spending will now be as roundly exaggerated as was its mathematical determinancy only a short time back.

One may point out, without being mischievous, that the concern of some federal bureaus for the consumer relates to speculation-even though not idle-as to what might happen to the credit user in the future. This future of foreboding may be distant, imminent, or intermediate. It may see inflation or recession. But one thing seems certain: that the consumer as a lump in economic life who uses great gobs of another statistical lump called consumer credit is bound to be considered somehow.

Meanwhile, every day, in hundreds of communities, real entities called persons are paying exorbitant usurious actual dollars for credit, and these dollars represent losses to individual and family living standards.

The Kansas City Star, August 5, I953, carried a story headed:

\section{"LOAN RATES STIR}

\section{Kansas Takes Legal Action Against Forty-Two Companies} in Five Cities

'UP to r,040 Per Cent'"

The first paragraph of the article read, "Topeka, Aug. 5:-The state launched an all-out effort today to put loan sharks out of business in Kansas."

Very commendable. But almost exactly a quarter century ago this writer, as a director of the Russell Sage Foundation, was giving assistance to another Kansas Attorney General in his helpful drive against loan sharks, and to a committee of the legislature considering the Uniform Small Loan Act. The newspaper headlines were almost the same. One line from the Star's recent article is so familiar that it might have been lifted intact from the newspaper's morgue. The present Attorney General was quoted as follows: "My office has checked the files in the federal bankruptcy court and found hundreds of cases where wage-earners of Kansas have been forced to invoke the wage-earner provisions of the bankruptcy statute."

The economist might say that the Kansas experience indicates effective demand. With knowledge that credit to consumers is available in Kansas cities from specialized agencies at moderate rates, the economist would note that the Kansas market

\footnotetext{
- Arthur F. Burns, The Instability of Consumer Spending 9 (Nat. Bur. Econ. Res., Inc., May, 1952).
} 
for consumer credit is not a pure example of a perfectly competitive market, as Theodore O. Yntema pointed out in $193^{8.7}$

The social workers would probably agree with the Attorney General's comment that Kansas needs a small loan law.

\section{B. Changes in the Lending Pattern}

The necessitous borrower was the main reference figure in the drafting of the original small loan legislation. Central to the framework of the law was recognition that practically all wage and salaried workers had to borrow for emergent purposes at times. If a licensed lender were available, loans would be made and repaid without undue disturbance to the continuity of the life of the borrower. In the absence of a legitimate source of credit, persons in need, under compulsion, would turn to the loan shark, with additional stresses resulting.

In the intervening years, persons without bank credit but still not in desperate necessities, have grown accustomed to handling many items of family affairs with the use of credit. The cost of credit has become a cost of the going business of families, and the cost can be ruinous, and so can overloading, particularly when an interruption to the high flow income occurs.

It seems reasonable to state that the protection of the consumer is recognized as being tinged with the public interest. In dealing with consumer problems, the economist, the government bureau, and the law maker, but less so the business man, tend to regard the individual in only part of his many functions. He becomes a global statistical unity, reduced often to an average, and appears only as a borrower, or a saver, or a person with disposable income, or a retail purchaser, or perhaps just some other figure-head. All are useful, all can be dangerous.

Taken alone, the figures on the rise in borrowing justify uneasiness. Taken alone, the ratio of consumer debt to disposable income, or the comforting figures on savings are offsets to alarm.

Neither are directly in point with the central thesis of this paper that many users of consumer credit, because of widening and expanding use, taken together with the possibility of reduced disposable income, stand in need of additional protection. This protection should take the form of (a) improved legislation in most states, and (b) adequate legislation where none exists now.

\section{Is Consumer Debt Too Large?}

The factors provoking the controversy over the volume of debt are important to the protection of borrower transactions.

Considering the economic health of the average individual, the separate averages combine to support those who are not disturbed by consumer debt increase.

Consumer debt is at its peak. The rise, except for short run periods, has not out-paced the growth of personal income. The ratio of such debt to disposable income, though perhaps at its highest, is still not unmanageable in terms of income,

"Yntema, The Market for Consumer Credit: A Case in "Imperfect Competition," I96 AnNals 79 (March, r938). 
which is still rising. This ratio cavorts up and down from year to year, and from quarter to quarter within the year, without reference to prosperity status. Sometimes it halves, sometimes it triples from quarter to quarter.

Nearly one-half of the installment debt was contracted for automobiles, and two-thirds was contracted for consumer goods. These, less depreciation, represent substantial assets, recognized now by many authorities as true savings, though they have limited liquidity for discharging money debts.

Individuals have savings, too, as offsets to their debts. While it is probably true that borrowers who turn to installment credit have lower savings ratios than nonborrowers, the liquid savings of borrower groups which have been studied have always proved to be substantial and widely-held.

The use of over-all savings statistics, which show the average American is a steady saver, is dangerous in the sense expressed earlier in this article. Over a period of sixty years the secular rate of growth in savings has been similar to national income. But each year has been higher or lower than the previous year by 50 per cent! The top ro per cent of the income units, however, accounted for 80 per cent of the savings, and this top group cannot be said to have acquired 80 per cent of the consumer debt.

There are changing patterns in American life which vitally affect the motives for personal savings and most of these changes undoubtedly will alter and are altering the propensity of the individual to expand his credit obligations. ${ }^{8}$

One is the result of compulsory saving for governmental unemployment and old age insurance, and the spread of private insurance and pension plans.

Another has been the increasing emphasis on ownership of consumer durable goods, such as automobiles, and on ownership of homes. The increase in the proportion of families living in owned homes was from 37 per cent in 1900 to 46 per cent in $193^{\circ}$ and 54 per cent in $195^{\circ}$.

In addition, there is noticeably less emphasis on leaving a substantial estate.

Where these three factors are in combination to afford a greater sense of security to the individual, and there are expectations of continued high-level income, it would seem that greater use of credit would result, such as for home repair and modernization loans, and for those new durables which can be had for use at once on the installment plan.

\section{Consumer Choice}

Some part of the answer as to the shape of consumer-credit things to come is hinged to the individual's ability, in his capacity as borrower, to exercise intelligent judgments. We have noted that a great part of credit extension today cannot be classed as "necessitous loans." Will the borrower, fortified by his savings, his share in social security, and his low ratio of credit needs to disposable income, soon reach that happy stage where the state no longer needs to afford special protections?

${ }^{8}$ Credit is due from the writer to R. W. Goldsmith's unpublished memoranda on savings. 
Can we soon come to rely only on the usual protections of the market place of prohibitions against misbranding, false advertising, and fraudulent practices?

The prospect is not that bright.

As Arthur F. Burns ${ }^{2}$ has pointed out the consumer is rarely a heroic figure. Until recently in economic thought he was the creature of a demand curve, where the "universal rule" was that the lower the price of a commodity the larger the amount which the public will seek to purchase. As Burns states, the Great Depression paved the way for a major shift in this economic theory. Prices did decline, but larger purchase possibilities were swamped by the opposing effect of declining income.

It remained for Keynes, with his thesis of the propensity to spend, to declare as a "fundamental psychological law" that "men are disposed, as a rule and on the average, to increase their consumption as their income increases, but not by as much as the increase in their income."

Soon the new economists, preoccupied by the deficiencies in aggregate spending of the thirties, had dropped all Keynesian qualifications. In theory, consumers again became creatures of habit, whose spending and savings were mathematical functions of income.

In the post-World War II world, the consumer rejected this captive role, and responded to many influences which are now being identified and studied.

Burns used the term "whimsical," to describe consumer spending, which might imply a measure of choice.

Certainly the consumer, as saver, played hob with the ratio of savings to disposable income. In 1947, when income went up, savings went down, and sometimes he was a dissaver, which is a nasty word even outside of Vermont. And in r95r, when wholesale prices seemed on the toboggan, personal saving was over 9 per cent of disposable income.

As income receiver, he had less to spend in I949 than he did in I948, and he spent more in 1949.

A mathematical formula summed up effectively the forces impinging on the volume of installment credit before I94I, but was quite ineffective for post-war conditions. ${ }^{10}$

A new term, "consumer discretionary spending power," was suggested to describe the volume of disposable income remaining after cost of food, clothing, housing, and household operation. This was said to have increased five-fold since r940, leaving the individual a greater range of choice, which presumably accounts for some deviations in traditional consumer behavior. Since the ratio of consumer credit to discretionary income was $3^{I}$ per cent in 1940 , and i8 per cent in 1952, it was suggested that consumer credit could expand 75 per cent without getting over extended!11

\footnotetext{
o The Instability of Consumer Spending, op. cit. supra note 6.

${ }^{10}$ Kisselgoff, Factors Affecting the Demand for Consumer Instalment Credit, Technical PAPER No. 7 (NAT. Bur. Econ. Res., I952).

${ }^{12}$ See Tide, August 29, 1953, p. 22 (published by the Billboard Publishing Co., Cincinnati, Ohio).
} 
The foregoing examples are not intended to be facetious or tendentious. Nor are they offered as proof that the consumer, in his whole set of functions, has attained freedom of choice. Burns would call most of these examples "jumps" which defy any equation. Some may be responses to postponed demand, or vagrant effects of a rapid inflation which has not completely worked itself out.

Undoubtedly the consumer, as householder, has achieved a certain choice of timing in the purchase of household inventories, and has some independence from the rigid spending-to-income formula.

But the savings ratio to national income, despite its "jumps," is confidently expected by students to conform to the long-term pattern.

And when borrowers increased their installment credits by 5 billion dollars in the year after May, 1952, they were responding in typical fashion. Lenders were free to lower down-payments and extend the length of the loan. Since income was rising, and there existed no consumer expectation of decline, then sales volume of durables could be increased as of yore. It has yet to be shown that the making of more attractive loan rates will add to more installment sales in a period of declining employment and payrolls.

In the Great Depression, despite the maintenance of the ratio between personal income and consumer debt, many borrowers were hurt by oppressive lender tactics, and there is no reason to believe the same would not happen again if the economy went into a tail-spin.

While borrowers, through widened use of multi-form credit, have become more sophisticated, it seems clear from recent records of overreaching, and the existence of high-rate loan sharks in many states, that corrective legislative regulation, and not relaxation, is needed in the days ahead. The inequality of bargaining power of the borrower in most consumer credit transactions persists as the mark distinguishing it from the purchase of commodities and services.

\section{IV}

\section{The Future of Consumer Credit Regutation}

Any forecast as to the future contour of personal credit regulation will contain some part of projection of strong movements now under way, some part of pure guesstimate, and several dashes of hope. The hope will dash better if it is not chilled by remembrance of the almost incredible power wielded at times by loan sharks in fending off legislation.

There is no uniform pattern of regulation, and the state by state approaches to change seem directed by a state right to be different.

Meanwhile most of the subterfuges and concealments intended to prevent the borrower from knowing the truth about his transaction are persisting, and new guises for collecting more interest revenue, such as credit insurance, are gaining ground.

There is little reason to believe that the growth of use of consumer credit will 
not continue, since this use has become an accepted part in family living and household management. And it is not too daring to venture that the percentage of disposable income so employed will go above the top limit which some federal authorities seem to regard as a maximum. If there are good standards of borrower protection, if the security of individuals continues to grow, and if the thesis of the Full Employment Act assures steady employment in practice, there should be no grave danger of overloading. Certainly there are many benefits now denied to low and medium income families by lack of finance, such as higher education of children, which rank as great as home modernization in the scale of satisfactions.

\section{Public and Business Support}

Passage of practically all satisfactory state loan regulation was accomplished with the support of (a) social agencies, (b) business groups interested in fostering decent business, (c) reputable loan companies prepared to do business under regulation, and (d) legislators who realized the need for special legislation.

In some states the help of the railroads, whose employees were harassed by salary buyers, was a great advantage, and in some admittedly their assistance had no strength.

At all times the legal aid societies, the better business bureaus, the junior chambers of commerce, and the junior bar associations, gave the type of professional, informed aid that could not be had otherwise.

It is not too much to expect that banks, insurance companies, business men's associations of all types would support better legislation.

Since most of the unregulated states are in the South, there is a possibility that old and new industries would join in campaigns.

In recent years, the licensed lenders seem to have avoided conflict with the loan sharks in the courts or in the legislative halls. No group has a larger stake in the integrity of small loan legislation-no group can testify better as to its worthiness.

Leadership is needed, of course, to rally all these forces, and to set a standard for standards.

\section{Legislation}

Judging mainly by the heat engendered in anti-loan shark campaigns, new legislation will be considered frrst in Texas, Kansas, and Arkansas, but the remaining 9 states without some form of small loan statute will be considering legislation soon.

Texas and Arkansas are states which have constitutional limits on interest, in addition to Oklahoma and Tennessee. This has been a barrier to high-rate lenders. Though amendment of the constitution is a long process, it is reasonably evident that the states will consider changing their constitutions to permit regulated lending at workable rates.

Public awareness to the need for regulation seems to have been awakened from the doze of the forties; and much livelier legislative campaigning seems sure. Cam- 
paigns will be organized separately, but one dares to hope that some time soon the work of eliminating the remaining loan sharks and providing decent credit will be made easier by (a) the pooling of energies and know how by all interested agencies, and (b) adoption of a set of standards and principles applicable to all forms of consumer credit extension. This may be visionary as to expectationit would be extraordinarily effective in practice.

For the near future, there will be piecemeal and patchwork legislative efforts, both as to the uniform or similar small loan laws and the special enabling acts for discount loan companies. There will be legislative proposals to legalize credit insurance lending and proposals to outlaw it for licensees.

How much better if the experience and knowledge of several years could be brought to bear on the preparation of a consumer credit code? 